\title{
ANETHOLEA ANISATA TRANSFERRED TO, AND TWO NEW AUSTRALIAN TAXA OF, SYZYGIUM (MYRTACEAE)
}

\author{
L.A. CRAVEN ${ }^{1} \&$ E. BIFFIN 1,2
}

\begin{abstract}
SUMMARY
The distinction between Anetholea and Syzygium is lessened due to the occurrence of epigeal germination and dry fruitedness in the latter genus also and it is concluded that Anetholea is better placed within Syzygium. Analysis of sequence data from nuclear ribosomal DNA and the chloroplast genome support this conclusion. The sole species of Anetholea, A. anisata, is transferred to Syzygium and the new combination, S. anisatum (Vickery) Craven \& Biffin, made. Syzygium wilsonii subsp. cryptophlebium is reinstated at species rank, necessitating the new combination, S. cryptophlebium (F. Muell.) Craven \& Biffin. Two new taxa of Syzygium are described from Australia, S. wilsonii subsp. epigaeum Craven \& Biffin and S. maraca Craven \& Biffin.
\end{abstract}

Key words: Anetholea, Syzygium, Myrtaceae, cpDNA, nrDNA.

\section{INTRODUCTION}

Backhousia anisata Vickery recently was found to be an anomalous member of Backhousia Hook. \& Harv. and moved to the new genus Anetholea Peter G. Wilson as its sole species (Wilson et al., 2000). The lack of any indumentum and possession of certain wood anatomical features were more consistent with a relationship with Syzygium Gaertn. and its allies than with the remaining species of Backhousia (Wilson et al., 2000). Because $B$. anisata possesses a dry fruit, leafy cotyledons and has epigeal germination, Wilson et al. (2000) concluded that it did not belong to an existing syzygioid genus and erected Anetholea to accommodate it. Our studies of the Syzygium generic complex in the Indo-Pacific have necessitated consideration of Anetholea anisata relative to the other species of the complex. Of the three features considered by Wilson et al. (2000) to be diagnostic at the generic level, our observations are that two of them, a dry fruit and epigeal germination, occur also in species of Syzygium. A dry fruit occurs in S. glenum Craven (Craven, 2003), albeit the tissues comprising the pericarp in S. glenum may not be homologous with those in A. anisata, the fruit wall of which is chartaceous in the dried state. Other species of Syzygium have somewhat dryish, at least not fleshy or succulent, fruit also. Hyland (1983) has recorded several species with non-fleshy fruit as follows: S. boonjee B. Hyland, fruits are "somewhat spongy"; S. bungadinnia (F.M. Bailey) B. Hyland, fruits are firm; S. crebrinerve (C.T. White) L.A.S. Johnson, pericarp more or less mealy; S. gustavioides (F.M. Bailey) B. Hyland, fruits have

1) Australian National Herbarium, CPBR, CSIRO Plant Industry, G.P.O. Box 1600, Canberra, ACT 2601, Australia.

2) Division of Botany \& Zoology, Australian National University, Canberra, ACT 0200, Australia. 
a leathery pericarp; S. hodgkinsoniae (F. Muell.) L.A.S. Johnson, pericarp is firm; S. kuranda (F.M. Bailey) B. Hyland, pericarp is firm, somewhat brittle and granular in texture. Notwithstanding the apparent histological diversity in the tissues comprising the fruit wall in Syzygium species, the taxonomic significance of which is yet to be investigated, it seems that dryness per se may not be a character of significance for higher level classification. Epigeal germination has been recorded as occurring in several Syzygium species by Henderson (1949), Hyland \& Whiffin (1993) and Hyland et al. (2003), i.e. S. attenuatum (Miq.) Merr. \& Perry (as Eugenia attenuata Miq.), S. branderhorstii Lauterb., S. campanulatum Korth. (as E. oleina Wight), S. conglomeratum (Duthie) I.M. Turner (as E. conglomerata Duthie), S. erythrocalyx (C.T. White) B. Hyland, S. luehmannii (F. Muell.) L.A.S. Johnson, S. nervosum DC., S. pustulatum (Duthie) Merr. (as E. pustulata Duthie) and S. trachyphloium (C.T. White) B. Hyland, and is a feature of a new taxon, S. wilsonii subsp. epigaeum Craven \& Biffin, that is described below. On present knowledge, the possession of leafy, obvolute cotyledons appears to be the only distinction between A. anisata and the other syzygioid species. Wilson et al. (2000) state that there "is some evidence, however, that the embryo of Syzygium has developed from an ancestor with leafy, obvolute cotyledons; it is apparent, in some species at least, that the thick cotyledons are interlocked in an obvolute fashion (e.g. Hyland, 1983: figs 2.35, 4.2)". This is in accordance with our own observations of fruits of Syzygium; rarely are the two opposing faces of the cotyledons more or less flat and a tendency towards being obvolute is not uncommon.

Analysis of DNA sequence data from comprehensive samples of species of the Syzygium generic complex suggest that Anetholea belongs within a broadened circumscription of Syzygium. Harrington \& Gadek (2004), in an analysis of sequence data from internal transcribed spacer (ITS) and external transcribed spacer (ETS) regions of the nuclear ribosomal DNA repeat from 66 syzygioid taxa, found that Anetholea nested within the ingroup taxa, consisting of species of Acmena DC., Acmenosperma Kausel, Syzygium and Waterhousea B. Hyland as these four genera were defined by Hyland (1983). In a combined analysis of ITS and ETS data, the relationship of A. anisata was unresolved within a polytomy of eight clades (containing most of the Syzygium taxa and all of Acmena, Acmenosperma and Waterhousea) that was sister to a well-supported clade of six Syzygium taxa (Harrington \& Gadek, 2004). Harrington $\&$ Gadek's results are reinforced by analysis of three cpDNA data sets ( $m a t K, n d h F$, rpl16) in which the position of Anetholea is consistently resolved amongst ingroup taxa, including Syzygium, Acmena, Acmenosperma and Waterhousea species (Biffin, unpublished data). Consideration of the morphological evidence, together with that obtained from molecular data, has led us to conclude that Anetholea falls within the circumscription of Syzygium and that A. anisata should be transferred to the latter genus.

Ongoing studies into Australian species of Syzygium have resulted in the recognition of a new species allied to $S$. alliiligneum B. Hyland, and a new subspecies within S. wilsonii (F. Muell.) B. Hyland. These are described below. The status of S. wilsonii subsp. cryptophlebium (F. Muell.) B. Hyland was considered and, in view of the several differences from $S$. wilsonii subsp. wilsonii, its elevation to species rank is warranted and is effected below. 


\section{Syzygium anisatum (Vickery) Craven \& Biffin, comb. nov.}

Backhousia anisata Vickery (1941) 129. - Anetholea anisata (Vickery) Peter G. Wilson in Wilson et al. (2000) 434. - Type: Rickerby s.n. (holo NSW n.v.), New South Wales, Bellingen, 26 October 1939.

2. Syzygium cryptophlebium (F. Muell.) Craven \& Biffin, comb. nov.

Eugenia cryptophlebia F. Muell. (1875) 144. - Syzygium wilsonii subsp. cryptophlebium (F. Muell.) B. Hyland (1983) 135. - Type: Dallachy s.n. (holo MEL; iso MEL, NSW), Queensland, Rockingham Bay.

Eugenia sordida F.M. Bailey (1892) 15. - Type: Bailey s.n. (holo BRI n.v.; iso MEL), Queensland, Mt Bellenden Ker, alt. about $1430 \mathrm{~m}$.

Eugenia macoorai F. M. Bailey (1892) 15. - Type: Bailey s.n. (holo BRI n.v.; iso MEL), Queensland, near the summit of the $\mathrm{S}$ peak of Bellenden Ker.

Eugenia rhadinantha S. Moore (1917) 303. - Type: Gibbs 6350 (holo BM n.v.; iso NSW), Queensland, Kuranda.

Note - Hyland (1983) treated Eugenia cryptophlebia as a subspecies of Syzygium wilsonii. Although the two taxa are clearly related, the differences are such that separate recognition at species rank is warranted. Syzygium cryptophlebium forms a tree to $30 \mathrm{~m}$ tall, has persistent, non-peeling branchlet bark, white or cream staminal filaments and mauve or purple fruit at maturity. In contrast, S. wilsonii is a shrub or tree to $9 \mathrm{~m}$ tall, has peeling branchlet bark, staminal filaments that are red, purple or pink and fruit that are white or cream at maturity.

3. Syzygium wilsonii subsp. epigaeum Craven \& Biffin, subspec. nov.

A S. wilsonii (F. Muell.) B. Hyland subsp. wilsonii filamentis staminalibus roseis, sepalis exterioribus longioribus (1.5-2 mm longis), disco staminali declinato, et germinatione epigaea differt. - Typus: Ford 4359 (holo BRI; iso A, CANB, K, L, MEL, NSW, P, QRS n.v.), Australia, Queensland, National Park Reserve 904, Wooroonooran, Coolamon Creek, c. $700 \mathrm{~m} \mathrm{~S}$ of Towalla Mine, c. $18 \mathrm{~km}$ SE of Malanda, 15 July 2004.

Tree or shrub to $9 \mathrm{~m}$ tall, to $5 \mathrm{~cm}$ dbh. Branchlets terete, compressed or quadrangular, winged or not, $1.2-2.5 \mathrm{~mm}$ in diameter; bark dull, smooth or slightly striate, peeling. Leaf lamina narrowly ovate or narrowly elliptic (occasionally oblong, rarely ovate), $7-19.4$ by $2-6 \mathrm{~cm}, 2-5.4$ times as long as wide, base cordate, rounded or obtuse, apex acuminate to narrowly acute, primary and secondary venation distinctly different with secondaries relatively little developed and not joining the intramarginal vein, primary veins 16-29 on each side of the midrib, divergence angle more or less uniform, in the median part of the lamina at an angle of $65-75^{\circ}$ and $4-11 \mathrm{~mm}$ apart, intramarginal vein present and $1.6-4.2 \mathrm{~mm}$ from the leaf margin, secondary intramarginal vein present or absent, oil dots not visible to the unaided eye in transmitted light, the dots small, sparse. Petiole $2-7$ by $0.9-2 \mathrm{~mm}$, stipules and/or axillary enations present or absent. Reproductive seasonal growth unit with a reproductive zone only. Inflorescence leafless, among the leaves (rarely below the leaves), terminal, distal axillary or lateral, few- to many-flowered, paniculate, the main axis straight and rigid and 1.5-2 mm thick at the mid point, $2.5-6$ by $4-6 \mathrm{~cm}$; bracteate, the bracts deciduous; bracteoles subtending each flower or subtending the lateral flowers of a triad with the terminal flower ebracteolate, deciduous. Flowers pink (calyx recorded by collectors as creamy 
pink or pink, corolla as creamy pink, creamy white or white, filaments as bright pink or pink, and anthers as white or pink), not calyptrate. Hypanthium dull, visibly gland dotted, stipitate or not (and then tapering evenly to the base or truncate or rounded), narrowly obconic or stipitately very narrowly obconic, $8-9$ by $3.5-4 \mathrm{~mm}$, stipe $0-2$ $\mathrm{mm}$ long. Sepals 4 , inner sepals larger than outer sepals or the sepals uniform in size, transversely-semicircular or semielliptic, persistent, not accrescent, 1.5-2.5 $\mathrm{mm}$ long when all are uniform in length, outer pair 1.5-2 mm long, inner pair 2-2.5 mm long. Petals 4, deciduous, not coherent, clawed or not (if clawed, shortly so), 2.5-3.5 by 2.5-3.5 mm, the margin lacerate or entire. Staminal disc descending. Stamens all fertile, outermost stamens 10-18 mm long, the filaments inflexed in bud; anther sacs parallel, narrowly-elliptic or narrowly oblong; anthers $0.6-0.8$ by $0.3-0.4 \mathrm{~mm}$, dehiscing by longitudinal slits; connective glands small or absent. Style $12-19 \mathrm{~mm}$ long at anthesis. Placentation axile-median, placenta very narrowly V-shaped, with the 2 apical arms well distinct, peltate despite its more or less linear shape. Ovules 16-22 per locule, spreading, arranged in two longitudinal rows. Mature fruit white or cream, obovoid and flat at the top or ellipsoid (obovoid in vivo), 13-20 by $9-16 \mathrm{~mm}$, with the calyx rim not appreciably expanding in fruit, the ovary apex domed, pericarp thick relative to the size of the seed and adhering to the seed without peg-like intrusions into it; germination epigeal. Seed 1, ellipsoidal, $8 \mathrm{~mm}$ in diameter, testa present, uniembryonic; embryo with the cotyledons readily separable and no interlocking funicular tissue present, equal in size or nearly so.

Distribution - Australia (Queensland, the Danbulla to Topaz region).

Habitat - Rain forest; 610-720 m altitude.

Notes - 1. Flowers have been recorded from May to October. Fruits recorded in October and January.

2. As the differences between this taxon and $S$. wilsonii subsp. wilsonii are relatively minor other than the mode of germination, inclusion within S. wilsonii at the rank of subspecies is deemed appropriate.

3. The subspecific epithet is derived from the Greek epi, over, on and ge, earth, in reference to the epigeal mode of germination.

Specimens studied:

Connors 139; Cooper \& Cooper 1730; Ford 4359 (type); Gray 2268, 2633, 5322, 5777, 7749, 7912; Irvine 1640; Jones 18767; Sankowsky \& Sankowsky 1608.

\section{Syzygium maraca Craven \& Biffin, spec. nov.}

A S. alliiligneo B. Hyland inflorescentia 1-4-flora, stylo longiore (40-41 mm longo), fructu pyriformi longioreque (55-110 mm longo), et semine subreniformi differt. - Typus: Irvine 771 (holo CANB; iso QRS), Australia, Queensland, Timber Reserve 1230, Boonjie Logging Area, c. 17 km ESE of Malanda (off Gourka Road), 12 March 1974.

Tree to $24 \mathrm{~m}$ tall, to $70 \mathrm{~cm}$ dbh. Bark brown to red-brown, papery, flaky. Branchlets terete or compressed, rounded, angled or winged, 1.5-2 $\mathrm{mm}$ in diameter; bark dull to glossy, smooth or slightly striate, persistent. Leaf lamina elliptic or narrowly elliptic or obovate, $4-13$ by $2.3-6 \mathrm{~cm}, 1.7-2.5$ times as long as wide, base symmetrical or oblique, cuneate or attenuate, apex short to long acuminate, primary and secondary venation distinctly different with the secondaries relatively little developed and not joining the intramarginal vein, the primary veins $8-16$ on each side of the midrib, the 
divergence angle more or less uniform, in the median part of the lamina at an angle of $50-70^{\circ}$ and $3-8 \mathrm{~mm}$ apart, intramarginal vein present and $1.5-3 \mathrm{~mm}$ from the margin, secondary intramarginal vein present, oil dots visible to the unaided eye in transmitted light, the dots small, sparse to dense. Petiole 5-20 by 1-2 mm, stipules and/or axillary enations not seen. Reproductive seasonal growth unit with a reproductive zone only. Inflorescence leafless, among the leaves, terminal or distal axillary, 1-4-flowered, cymose, $2.5-6$ by $1-5 \mathrm{~cm}$, main axis straight and rigid and $0.75-1.5 \mathrm{~mm}$ thick at the mid point, bracteate, bracts deciduous, bracteoles subtending each flower or subtending the lateral flowers of a triad and with the terminal flower ebracteolate, deciduous. Flowers not calyptrate, white or cream. Hypanthium dull (or glossy due to an exudate from the outer hypanthium wall), not visibly gland dotted, stipitate-campanulate or narrowly so, $9-22$ by 5-6 mm, stipe 1-10 mm long. Sepals 4, inner pair larger than the outer, subcircular, persistent, not accrescent, outer pair of sepals 3.3-6 mm long, inner pair 5-7.7 mm long. Petals 4, early deciduous, not coherent, 8-16 by $7.5-12$ $\mathrm{mm}$, the margin entire. Staminal disc lipped. Stamens all fertile, outermost stamens 22-33 mm long, filaments inflexed in bud, anther sacs parallel, narrowly-elliptic or narrowly-oblong, $1.5-2$ by $0.7-0.9 \mathrm{~mm}$, dehiscing by longitudinal slits, connective glands absent. Style 40-41 mm long. Placentation axile-median, placenta an hemiellipsoid cushion. Ovules 15-30 per locule, ascending, arranged irregularly. Mature fruit red or glossy dark red, pyriform (often curvedly so, the stipitate portion short or long), 55-110 by $28-55 \mathrm{~mm}$, with the calyx rim not appreciably expanding in fruit, the pericarp thin relative to the size of the seed, relatively fleshy, distinctly free from the seed and without peg-like intrusions into the seed. Seed 1, subreniform, 30-35 mm across, testa present, uniembryonic; embryo with the cotyledons readily separable and no interlocking funicular tissue present, equal in size or nearly so.

Distribution - Australia (Queensland, Daintree and Topaz regions).

Habitat - Rain forest; 15-720 m altitude.

Notes - 1. Flowers have been recorded in February, March and July. Fruits have been recorded in June, September to November, and January.

2. Hyland (1983) assigned flowering and sterile specimens of S. maraca to $S$. alliiligneum although he apparently suspected then that they might prove to represent a distinct species (B. Gray, pers. comm.). With the more recent collection of fruiting specimens, it is clear that two quite different species are involved. The pyriform fruit and much reduced inflorescence readily distinguish this species from S. alliiligneum. Sterile herbarium material can also be named as the leaves of $S$. maraca feel soapy to the touch, in some cases sticky, whereas the leaves of $S$. alliiligneum lack any such tactile qualities.

3. The specific epithet is a noun in apposition. Well-developed fruit of this species are extremely similar in shape to the musical instrument, maraca. In addition, the pericarp separates from the seed at maturity thus enabling the seed to rattle within the cavity when the fruit is shaken.

4. The ability of $S$. maraca to produce large fruits which, fide G. Sankowsky (pers. comm.), are extremely palatable indicates that this species is worth investigation with a view to its development as a commercial fruit crop.

Specimens studied:

Cooper \& Cooper 1605; Gray 2634, 4912; Irvine 31, 769, 771 (type), 1211, 1378; Jensen 480; Sankowsky 1438; Sankowsky \& Sankowsky 1592, 1623; Telford \& Donaldson 12194. 


\section{ACKNOWLEDGEMENTS}

The Directors and/or Curators of the following herbaria are thanked for the opportunity to study collections in their care: CANB, QRS. The following are thanked for sharing their knowledge of the plants discussed in this paper and/or for providing material for study: Wendy Cooper, Andrew Ford, Bruce Gray, Garry Sankowsky and Peter Wilson. Mark Harrington and Paul Gadek generously allowed us advance access to their paper. Ed Biffin holds an ABRS Postgraduate Scholarship from the Australian Biological Resources Study and a Scholarship from the Australian National University; this support is gratefully acknowledged.

\section{REFERENCES}

Bailey, F.M. 1892. Eugenia Linn. Contributions to the Queensland Flora. Queensland Dept. Agric. (Bot. Bull. No. 5) Bull. No. 18: 15-16.

Craven, L.A. 2003. Four new species of Syzygium (Myrtaceae) from Australia. Blumea 48: 479-488.

Harrington, M.G. \& P.A. Gadek. 2004. Molecular systematics of the Acmena alliance (Myrtaceae): phylogenetic analyses and evolutionary implications with reference to Australian taxa. Austral. Syst. Bot. 17: 63-72.

Henderson, M.R. 1949. The genus Eugenia (Myrtaceae) in Malaya. Gard. Bull. Singapore 12: $1-293$.

Hyland, B.P.M. 1983. A revision of Syzygium and allied genera (Myrtaceae) in Australia. Austral. J. Bot., Suppl. 9: 1-164.

Hyland, B.P.M. \& T. Whiffin. 1993. Australian tropical rain forest trees. CSIRO, East Melbourne.

Hyland, B.P.M., T. Whiffin, D.C. Christophel, B. Gray \& R.W. Elick. 2003. Australian tropical rain forest plants: trees, shrubs and vines. CSIRO, Collingwood.

Moore, S. 1917. Eugenia rhadinantha. In: L.S. Gibbs (ed.), A contribution to the phyto-geography of Bellenden-Ker. J. Bot. 55: 297-310.

Mueller, F. 1875. Eugenia cryptophlebia. In: F. Mueller, Fragm. Phytogr. Austral. 9. George Skinner, Melbourne.

Vickery, J. W. 1941. Backhousia anisata: a new species of Myrtaceae. Contr. New South Wales Natl. Herb. 1: 129-130.

Wilson. P.G., M.M. O'Brien \& C. J. Quinn. 2000. Anetholea (Myrtaceae), a new genus for Backhousia anisata: a cryptic member of the Acmena alliance. Austral. Syst. Bot. 13: 429-435. 